\title{
Financial Leverage and Corporate Performance: Does Financial Crisis Owe an Explanation?
}

\author{
Syed Jawad Hussain Shahzad \\ COMSATS Institute of Information Technology, Islamabad, Pakistan \\ jawad.kazmi5@gmail.com \\ Paeman Ali \\ COMSATS Institute of Information Technology, Islamabad, Pakistan \\ paemagn.ali@gmail.com \\ Tanveer Ahmad \\ COMSATS Institute of Information Technology, Islamabad, Pakistan \\ tanveer@vcomsats.edu.pk
}

\section{Sajid Ali}

PhD Scholar UMT Malaysia

sajid.mahr@gmail.com

\begin{abstract}
The objective of this study is to investigate the impact of financial leverage on corporate financial performance of Pakistan's textile sector from 1999-2012 using panel data. The leverage-performance relationship is examined with a special focus on the Global Financial Crisis of 2007-2008. Both accountingbased (Return on Assets - ROA) and market-based (Tobin's Q) measures of corporate financial performance are used. Regression analysis is performed with and without inclusion of financial crisis dummy. Total Debt to Total Assets (TDTA), Long Term Debt to Total Assets (LDTA), Short Term Debt to Total Assets (SDTA) and Debt to Equity (DE) ratios are used as proxies for financial leverage whereas firm's size and firm's efficiency are used as control variables. The results indicate that financial leverage has a negative impact on corporate performance when measured with ROA. Whereas in case of Tobin's Q, SDTA coefficient is positive. It can be concluded that since cost of borrowing is high in Pakistan and debt capital markets are less developed, firms are forced to resort to banks as their source of debt finance and thus have to repay huge amount of principal and interest which has a heavy toll on their financial health. In addition to this, financial crisis was found to have a negative impact on corporate performance and also affect the leverage-performance relationship.
\end{abstract}

Keywords: Capital structure, financial leverage, corporate performance, financial crisis

\section{Introduction}

Every firm needs financing to invest in different assets in order to operate efficiently, i.e. to provide tangible or intangible products (i.e. services) to its customers. The need to raise funds for successful operations gives rise to a very crucial concept in corporate finance, the capital structure ${ }^{1}$. The capital structure decisions of a firm's management have a significant bearing on a firm's financial performance and since firms operate in different sectors of the economy, the impact that those decisions can have on a firm's financial performance is bound to be different across various industrial sectors owing to the fundamental differences

\footnotetext{
${ }^{1}$ A company's capital structure is the mix of debt and equity the company uses to finance its business. Source: Chartered Financial Analyst (CFA) Level 2, Book 3
} 
in firms' capital structures. The level of debt financing that a firm uses in its capital structure is referred to as financial leverage. Financial leverage has been documented to affect firm's financial performance in many empirical studies in the capital structure literature (San \& Heng, 2011; Salim \& Yadav, 2012; Khan, 2012), though no conclusive relationship has yet been documented and further research in the area has been encouraged lately.

In Pakistan, the capital markets (especially bond markets) are less developed as compared to the developed economies and the cost of debt financing is also comparatively higher which makes it difficult for Pakistani firms to obtain debt financing on low interest rates. Firms' sizes are generally small and they lack technical ability and financial soundness for issuing long-term debt in the capital market. So, firms usually opt for bank loan financing on a short-term basis or internal source of funds (Shah, Hijazi, \& Javed, 2004; Khan, 2012). Only large firms with good financial health are able to issue long-term debt but they too are forced to limit their financing options to bank loan financing among a few long-term financing options available in the debt market (Khan, 2012). Due to information asymmetry problems in the equity markets and underdevelopment in the bond markets, debt financing through bank loans appears to be the most preferred choice of financing for corporations in Pakistan. Firms have been noticed to raise their debt levels, especially from 2006 onwards with a corresponding declining pattern in profitability ${ }^{2}$. Apparently, there seems to be a negative relationship between financial leverage and profitability from 2006 onwards. However, no such relationship is discernible before 2006.

Despite the criticality of debt financing in capital structure decisions that firms face in the context of high borrowing costs and less developed capital markets, the financial leverageperformance relationship has attracted far less attention in Pakistan. Most of the studies examining this relationship have been conducted in developed economies where capital markets are developed. Clearly, their findings cannot be considered for policy formulation in Pakistan as the context is entirely different. Only a few studies have examined this relationship in Pakistan's context recently (Khan, 2012; Akhtar et. al., 2012) which have concluded with mixed findings and have encouraged further research in this strand of literature by using more comprehensive proxies to enhance the utility of results for policy making and firm-level managerial support.

The global financial crisis wave of 2007-2008, having its epicenter in the United States of America (USA), hit the South Asian economies in 2008 (Amjad \& Din, 2010). However, the level of impact varied from one country to another. The channels of transmission of this wave (from USA to South Asian economies) depend on the extent to which these economies are financially integrated with the epicenter of this wave (i.e. the USA). Major channels have been identified by Amjad \& Din (2010) which help in identifying the beginning of impact of the financial crisis wave in the South Asian economies. These channels include exports of goods and services and stock market volatility. Europe and USA are the major markets for South Asian exports. During the financial crisis, demand for South Asian exports declined in these markets and export growth also declined in these exporting economies as a result. Consequently, these economies experienced forgone

\footnotetext{
${ }^{2}$ Source: Balance sheet analysis of non-financial sector of Pakistan (2003-2011)
} 
income from exports and greater current account deficit. This effect of propagation of the financial crisis wave from its epicenter to rest of the world is called financial contagion effect. Pakistan's economy had its own share of impact from the financial crisis wave owing to the contagion effect ${ }^{3}$. Growth rate of export earnings of Pakistan fell by $6.4 \%$ in 2009 (as compared to the highest growth rate of 18.2\% achieved in 2008). Foreign Direct Investment (FDI) in Pakistan took a steep fall and stood at \$3209 million in 2009 (as compared to $\$ 5078$ million in 2008). The stock market in Pakistan did not remain unharmed during the impact. In fact, KSE-100 index which is a major stock market index was the only indicator which marked the beginning of impact of the global financial crisis wave in Pakistan even before other indicators did. The KSE-100 index fell from 14,814 points in December 2007 to 5,865 points in December 2008 and further dropped to 4,929 points in January 2009. All these facts, accompanied with rising inflation rate and weakening economic growth in the years 2008 and 2009 marked the entry of the crisis wave in Pakistan. However, the economy started the recovery process in the latter half of 2009.

Amidst the mixed findings regarding the relationship between financial leverage and corporate financial performance observed during literature review, and lack of focus on financial crisis's impact on the said relationship, there is a need for a comprehensive study to investigate the true nature of relationship between financial leverage and firm's financial performance and to ascertain the nature of impact that financial crisis had on corporate performance. Rising corporate debt level observed from 2006 onwards using the descriptive analysis provides an insightful hint regarding the presence of a financial crisis (2007-2008) explanation to the apparently changing nature of the leverage-performance relationship observed after 2006. The lack of availability of reliable studies examining the leverage-performance relationship in Pakistan coupled with the absence of studies focusing on the possible impact of financial crisis on this relationship calls for a comprehensive study to fill this research gap.

This study aims to overcome the conceptual and econometric limitations in previous studies (e.g. Khan, 2012; Akhtar et al. 2012) conducted in Pakistan's context by utilizing appropriate panel estimation techniques for analysis, recently used proxies for estimation, larger sample period, and by including greater number of capital intensive firms from the textile sector in the analysis. Most importantly, this study is one of the first of its kind to investigate whether financial crisis explained financial performance of firms during the fourteen year period in the textile sector of Pakistan. This study overcomes the limitations of previous studies by incorporating two performance measures (ROA and Tobin's Q), larger sample period (i.e. 14 years from 1999-2012), comprehensive sample consisting of 112 textile companies, and variety of panel estimation techniques including pooled OLS, Fixed Effects, and Random Effects estimation techniques. The aim is to give a reasonable conclusion about the leverage-performance relationship and the impact of financial crisis on corporate performance based on the comparison among the estimation results obtained by using various performance measures and estimation techniques. The rest of the paper is

\footnotetext{
${ }^{3}$ Financial Contagion refers to a scenario in which small shocks, which initially affect only a few financial institutions or a particular region of an economy, spread to the rest of financial sectors and other countries whose economies were previously healthy, in a manner similar to the transmission of a medical disease. Financial contagion happens at both the international level and the domestic level.
} 
organized as follows. Section 2 provides the review of literature. Section 3 explains the data and methodology used in this study. Section 4 highlights the findings and Section 5 concludes the study. Final section suggest some practical implications based on the findings.

\section{Literature Review}

The relationship between capital structure and firms performance has been debated by several researchers over the decades. Murphy (1968) criticized the traditional theories that the amount of debt capital in a firm's capital structure has a favorable impact on its performance indicators including return on common equity, growth of earnings, price appreciation, and market valuation. As opposed to previous studies, Murphy's research contended that financial leverage does not explain firm performance and that firms having greater debt levels exhibit the same performance as those firms having low or no debt in their capital structures and the rationale behind these findings is that the stock price appreciation and changes in earnings in a particular period are independent of each other and do not exhibit any systematic pattern which might qualify as a determining factor of their relationship. This uncertainty in stock prices and other performance measures coupled with stable debt ratios implies no relationship between firm performance and financial leverage. Additionally, the research contended that the ratios usually taken for measuring leverage are too complex to capture the true relationship among these variables.

Continuing the debate, Baker (1973) investigated the relationship between industry profitability and leverage and also incorporated the effect that risk may have on industry's profitability. Using the data for ten year period, leverage was measured as the ratio of equity to total assets (i.e. low value of leverage would imply higher use of debt capital) instead of debt to equity or debt to total assets. Whereas profitability was measured using after-tax profit rate. The study concluded that industry conditions influence the firms' choice of leverage and these findings are also empirically confirmed by MacKay and Phillips (2005). Baker (1973) also concluded that firms with higher debt capital had greater profitability. Firm's financing source can also contribute towards better profitability of firms and the use of financial leverage does materialize in positive benefits to financial health of a firm and this can also contribute towards better return on equity of these firms. Although greater debt level increases industry profitability it also induces higher risk (MacKay \& Phillips, 2005).

Using the data of 231 manufacturing firms, Hurdle (1974) investigated the relationship among leverage, risk, market share, and profitability and identified that firms with large market share and with relatively less risk (measured by standard deviation in annual profits) prefer lower debt in their capital structures since the focus of these firms becomes tilted towards stable profits. Additionally, firms with large market share and stable profits are usually monitored closely by the antitrust divisions and any move by the firm's management potentially leading to higher debt is severely criticized by these divisions and thus large firms with less riskiness prefer low debt. Here results clearly show that the use of financial leverage does not necessarily lead to higher corporate performance. Higher performance may be achieved even without the excessive use of debt capital. When a firm uses debt capital the shareholders enter into a conflict with the creditors (or debt holders) and force the firm's management to act in their interests instead of the interests of creditors. 
As a result, the management strives for better performance and would lead to enhanced corporate performance (Jensen \& Meckling, 1976). Short term debt to total assets has shown a positive relationship between financial leverage and corporate performance, the use of long term debt to total assets has shown a negative relationship (Abor, 2005).

Firms that produces highly specialized products and have high research and development expenditure would suffer decline in corporate performance (sales growth and stock performance) and productivity if exposed to high leverage (debt to asset ratio). The reason behind this decline in firm performance is evident from the fact that firms with highly specialized products have immensely great research and development expenditures which they have to meet at all costs to continue develop new products to retain market share. At this crucial stage, high debt levels renders the firm vulnerable to performance declines since they have to pay huge fixed amounts on their outstanding debt (Opler \& Titman, 1994). They based their findings on the analysis of 46,799 observations over a period 1972 to 1991.

Salim \& Yadav (2012) investigated the relationship between capital structure and firm performance for 237 listed Malaysian companies over a period of 1995-2011. The relationship between financial leverage and performance was found to be negative when performance was measured using Return on Assets (ROA) and Return on Equity (ROE) whereas it was positive when performance was measured using Tobin's Q ratio. The leverage-performance relationship was found to be varying across different sectors and performance measures considered in the analysis. Similar, San \& Heng (2011) estimated the leverage-performance relationship in the context of financial crisis of 2007 for all construction companies listed on the main board of Malaysia over a period of 2005-2008 and identified a positive relationship in some companies while negative in others.

Ebaid (2009) investigated the relationship between financial leverage and corporate performance in Egyptian context by analyzing the data of companies over a period from 1997-2005 using accounting based measures for corporate performance including Return on Assets (ROA), Return on Equity (ROE), and Gross Margin (GM). For measuring financial leverage three proxies were used that includes short term debt to total assets, long term debt to total assets, and total debt to total assets. Firm size was used as control variable in the analysis. The research concluded that the impact of financial leverage varies across different proxies for financial performance. The relationship was found to be negative when performance was measured by ROA and an insignificant impact was found when performance was measured by ROE or GM. Additionally; capital structure has little or no influence on the firms' performance in Egypt.

Bhabra, Liu, and Tirtiroglu (2008) studied the capital structure choice of Chinese listed firms from different industrial sectors including manufacturing, retail/services/trade, mining/resources, utility, real estate, and conglomerate over the period of 1992 to 2001. The measures used for financial leverage include long term debt to book value of assets, long term debt to market value of assets, total debt to book value of assets, and total debt to market value of assets. Their results showed that the long term debt usage in Chinese listed firms is far more less than that witnessed in firms of developed or other emerging economies and this fact is true even in periods of booming stock market activity in China. They argued that long term debt is mostly used by big firms. Some other factor which 
influence the capital structure decisions in China include information asymmetry and high financial contracting costs incurred by these firms. The reason for high costs is that the financial markets in China have been established for a very short period of time when compared with those of other emerging economies (e.g. stock market of Pakistan which was established in 1949). The financial markets of other emerging economies have a long history that's why the effect of asymmetric information is controlled to a much greater extent. Moreover, the major source of debt financing in China is banks. This also implies high borrowing costs for Chinese firms (similar to the case of Pakistani firms). High cost of borrowing is one of the reasons why only big firms borrow funds on long term basis. They also concluded that firm profitability and long term debt usage are negatively related in the case of Chinese firms and these findings are consistent with those presented by other studies on emerging and developing economies. Firm size and long term debt usage was found to be positively related.

Pakistan is one of many developing countries with less developed debt capital markets. Most of the non-financial firms in Pakistan prefer to raise funds in the money markets using short-term debt financing since the firms lack resources and technical ability to issue longterm debt (Shah, 2007). The corporate bond market is still in the development phase. Another option available to corporations is equity financing but it has its own problems including market inefficiency due to asymmetric information. These are a few reasons why corporations in Pakistan mostly prefer debt financing through bank loans as banks minimize the effect of asymmetric information to a reasonable extent. But the cost of borrowing is very high in Pakistan as compared to the developed economies. That is why only highly profitable (capital intensive) firms manage to raise a substantial amount of funds on a long term basis. Others either borrow on a short term basis on raise funds through internal sources of finance. These facts highlight the importance of debt financing in capital structure decisions for the capital intensive firms in Pakistan as they are forced to select among limited debt financing alternatives. The debt financing level for the nonfinancial firms in Pakistan has been rising since 2006 onwards followed by a decline in performance. No such pattern is discernible before 2006. This analysis is however based on preliminary descriptive analysis and is subject to further verification and requires empirical support. Empirical tests will be conducted in this study to verify these observations.

A few observations have also been made by other researchers regarding the capital structure choices of firms in public and private sectors of Pakistan. Qureshi and Azid (2006) have presented a lot of determining factors of capital structure choice in listed firms in Pakistan. They studied a huge sample of manufacturing firms (both public and private) over a period of twenty nine years. They hypothesized several variables as the determinants of capital structure choice including agency costs, taxes, non-debt tax shield, growth, firm size, assets' collateral value, assets tangibility, profitability, liquidity, and earnings variability. Leverage was measured by using total debt to total assets ratio, agency costs by operating expenses to sales ratio and sales to total assets ratio, taxes by tax provision to net profit before taxes, non-debt tax shield by depreciation for the year to total assets, firm size by taking natural log of total assets, assets' collateral value by fixed assets at cost to total assets, assets' tangibility by net fixed assets to total assets ratio, profitability by net income to total assets ratio, liquidity by using current assets to current liabilities, and earnings variability by changes in net profit before taxes. 
Despite all these facts, very few researchers have historically appreciated the importance of financial leverage in explaining corporate performance of the textile sector in Pakistan, especially in the context of financial crisis. Since textile sector is one of the biggest industrial sectors from borrowing point of view with high financing needs (both for working capital and capital expenditures), there is a need for a comprehensive study to examine the relationship between debt financing and its impact on the financial performance of textile sector firms in Pakistan. This study has an edge over other studies since it also explains the impact that financial crisis had on the financial performance of firms and whether the nature of relationship between financial leverage and financial performance was altered during financial crisis or not. A few studies could be found which examined the impact of financial leverage on corporate financial performance in different capital intensive sectors of the economy. Khan (2012) studied the relationship of capital structure decisions with firm performance for 36 engineering firms listed on the Karachi Stock Exchange (KSE) over a period of 2003-2009 and concluded that financial leverage (when measured using total debt to total assets) has a significant negative relationship with firm performance. This study presented a few limitations, this study considered engineering sector as the only capital intensive sector in Pakistan whereas there are many other capital intensive sectors that could have been considered (e.g. fuel and energy, textile, and food sectors). Another study conducted by Akhtar et. al. (2012) investigated the relationship between financial leverage and performance for 20 public limited companies from fuel and energy sector listed on the KSE by using descriptive and correlation analysis and found financial leverage to have a positive relationship with corporate performance and suggested that firms should consider increasing the debt level for value maximization purposes. This study lacked a major essential of quantitative research. The objective of this study was to evaluate the impact of financial leverage on corporate financial performance but no econometric technique was used to estimate the relationship. Correlation is a numerical measure which merely suggests the degree of linear association between two variables but does not explain the variation that one variable causes in another. Moreover, no control variables were used in the analysis. These are some of the few studies which have been conducted in Pakistan's context but they lack focus on financial crisis and most importantly, there are very few studies which explain leverage-performance relationship in the textile sector (one of the biggest corporate borrowers in the economy). This study attempts to fill this research gap.

\section{Data and Methodology}

The study sample consists of 112 listed companies from the textile sector of Pakistan. The data was obtained from the balance sheet analysis issued by the statistics and warehouse department of the State Bank of Pakistan (SBP) for a period of 14 years (1999-2012). The final data set comprises of 1,344 total observations. The dependent variable for this study is corporate financial performance which is measured by both market based and accounting based measures including Tobin's Q and Return on Assets (ROA) ratios. Independent variable for this study is financial leverage and has been measured by using short term debt to total assets, long term debt to total assets ratio, total debt to total assets ratio, and debt to equity ratio. Two control variables have also been used including firm size and firm efficiency. Firm size has been measured by taking logarithm of total assets of each firm in the sample and firm efficiency has been measured by using total asset turnover ratio of 
each firm in the sample. Besides this, a dummy variable for financial crisis has been used to account for the financial crisis impact. This dummy variable takes the value of 0 from 1999-2006 and in the years 2011 and 2012 where it takes the value of 1 from 2007-2010 since financial indicators in Pakistan marked the entry of the financial crisis wave in 2007 as suggested by Amjad \& Din (2010). This fact has also been highlighted in section 1. The definitions and further explanation of each of these proxies is given in appendix 1 .

Table 1: Expected Signs of the independent variables.

\begin{tabular}{cllc}
\hline $\begin{array}{c}\text { S. } \\
\text { No. }\end{array}$ & \multicolumn{1}{c}{ Variable(s) } & $\begin{array}{c}\text { Expected Sign with } \\
\text { ROA }\end{array}$ & $\begin{array}{c}\text { Expected Sign with } \\
\text { Tobin's Q }\end{array}$ \\
\hline 1. & Total Debt to Total Assets & Negative (-) & Negative (-) \\
2. & $\begin{array}{l}\text { Short Term Debt to Total } \\
\text { Assets }\end{array}$ & Negative (-) & Positive (+) \\
3. & Long term Debt to Total Assets & Negative (-) & Negative (-) \\
4. & Debt to Equity Ratio & Negative (-) & Negative (-) \\
5. & Firm Size & Positive (+) & Positive (+) \\
6. & Firm Efficiency & Positive (+) & Positive (+) \\
\hline
\end{tabular}

Note: ROA stands for return on assets.

Fixed Effects and Random Effects panel estimation models have been used for empirical analysis. Hausman test has been used to test for the issue of correlation of error term with the independent variables which is one of the assumptions of the Random Effects model. The violation of this assumption is tested using Hausman test. If this assumption is violated then Fixed Effects model is preferred over Random Effects model. FEM is a statistical model that represents the observed quantities in terms of explanatory variables that are treated as if the quantities were non-random (i.e. fixed). The equation for FEM is given below:

$$
\mathrm{Y}_{\mathrm{it}}=\alpha_{0 \mathrm{i}}+\alpha_{1} \mathrm{X}_{1 \mathrm{it}}+\alpha_{2} \mathrm{X}_{2 \mathrm{it}}+\mu_{\mathrm{it}}
$$

This model is used to take into account the individuality of each cross-sectional unit by allowing the intercept to vary for each cross-sectional unit while assuming the slope coefficients are constant across all the cross-sectional units. The subscript $i$ on the intercept term suggests that the intercepts of the cross-sectional units may be different. The differences may be due to special features of each cross-section. REM is a statistical model in which either all or some of the explanatory variables are treated as if they arise from random causes and intercepts for each cross-sectional unit are assumed to arise from a "global" intercept term plus a random variable. The equation for REM is given below:

$$
\begin{aligned}
Y_{i t} & =\alpha_{0}+\alpha_{1} X_{1 i t}+\alpha_{2} X_{2 i t}+\varepsilon_{i}+\mu_{i t} \\
& =\alpha_{0}+\alpha_{1} X_{1 i t}+\alpha_{2} X_{2 i t}+\omega_{i t}
\end{aligned}
$$

Where,

$$
\omega_{\mathrm{it}}=\varepsilon_{\mathrm{i}}+\mu_{\mathrm{it}}
$$

The composite error term $\omega_{i t}$ consists of two components, $\varepsilon_{i}$, which is the cross-section, or individual-specific, error component, and $\mu_{i t}$, which is the combined time series and crosssection error component. The term error components model derives its name because the 
composite error term $\omega_{i t}$ consists of two (or more) error components. REM assumes that each cross-sectional intercept arises from a common intercept term and a random variable which is constant over time but varies cross-sectionally. Hausman Test is used to compare two panel data models including Fixed Effects Model (FEM) and Random Effects Model (REM) and to find out whether REM generates coefficients which are similar to those generated by FEM. The null hypothesis $\left(\mathrm{H}_{0}\right)$ for this test is that the coefficients generated by both models are similar; whereas the alternate hypothesis $\left(\mathrm{H}_{1}\right)$ states that the there is a difference between the coefficients generated by the two models. Following two equations have been estimated using OLS, Fixed Effects, and Random Effects models.

$$
\begin{aligned}
& \mathrm{ROA}_{\text {it }}=\beta_{1 \mathrm{i}}+\beta_{2} \mathrm{SDTA}_{\mathrm{it}}+\beta_{3} \mathrm{LDTA}_{\mathrm{it}}+\beta_{4} \mathrm{TDTA}_{\mathrm{it}}+\beta_{5} \mathrm{DE}_{\mathrm{it}}+ \\
& \beta_{6} \text { SIZE }_{i t}+\beta_{7} \text { EFY }_{\text {it }}+\beta_{8} \text { FCDUM }_{\text {it }}+\mu_{\text {it }} \\
& \text { Tobin's } Q_{i t}=\beta_{1 \mathrm{i}}+\beta_{2} \text { SDTA }_{i t}+\beta_{3} \text { LDTA }_{i t}+\beta_{4} \text { TDTA }_{i t}+\beta_{5} \text { DE }_{i t}+ \\
& \beta_{6} \text { SIZE }_{i t}+\beta_{7} \text { EFY }_{\text {it }}+\beta_{8} \text { FCDUM }_{\text {it }}+\mu_{\text {it }}
\end{aligned}
$$

Where,

$\begin{array}{lll}\text { ROA } & = & \text { Return on Assets } \\ \text { SDTA } & = & \text { Short-term Debt to Total Assets } \\ \text { LDTA } & = & \text { Long-term Debt to Total Assets } \\ \text { TDTA } & = & \text { Total Debt to Total Assets } \\ \text { DE } & = & \text { Debt to Equity } \\ \text { SIZE } & = & \text { Firm Size } \\ \text { EFY } & = & \text { Firm Efficiency } \\ \text { FCDUM } & = & \text { Financial Crisis Dummy (0 from 1999-2006 and 2011-2012 } \\ \text { and 1 for 2007-2010) } & \end{array}$

The estimation has been carried out on both equations (1) and (2) using the above said panel estimation models (i.e. OLS, Fixed Effects, and Random Effects models). First, the equation was estimated using ROA and then by using Tobin's Q as a measure of corporate financial performance. While studying the relationship with each of these variables, the regression was run for the whole sample period with and without the impact of financial crisis. In this way, the exact nature of leverage-performance relationship in the textile sector of Pakistan can be ascertained not only in periods when markets were free from the financial crisis impact but also in periods when financial crisis was present in the market. The exact nature of the impact of financial crisis on corporate performance was ascertained with the help of dummy variable which is an alternative to Chow test for structural stability of a model. As indicated by Gujarati (2009) in Chapter 9, page 303, Chow test only tells about the existence of difference between two estimated regression equations as to whether they are significantly different from each other or not but it does not tell the nature of that difference. It can be done in a much better way using dummy variable technique. By using intercept dummy, one can tell whether fulfillment of a certain condition led to a change in a dependent variable or not and what that change was. As the use of intercept dummy leads to an intercept shift, it can be efficiently ascertained whether financial crisis affected the corporate performance positively or negatively by taking a look at the intercept in the regression equation where financial crisis dummy was included after comparing it with the estimated equation in which financial crisis dummy was not included. This technique can also be used to ascertain whether financial crisis affected the leverage-performance 
relationship and in what way. Further, a precise evaluation of how crises impacts different leverage measures and their relation with performance has been performed using FCDUM as an interaction term with all independent variables in equation (3) and (4).

$$
\begin{aligned}
& \mathrm{ROA}_{i \mathrm{it}}=\gamma_{1 \mathrm{i}}+\gamma_{2} \mathrm{SDTA}_{\mathrm{it}}+\gamma_{3} \mathrm{LDTA}_{\mathrm{it}}+\gamma_{4} \mathrm{DE}_{\mathrm{it}}+\gamma_{5} \mathrm{SIZE}_{\mathrm{it}}+\gamma_{6} \mathrm{EFY}_{\mathrm{it}}+\gamma_{7} \mathrm{FCDUM}_{\mathrm{it}}+ \\
& \gamma_{8} \text { SDTA }_{\text {it }} * \text { FCDUM }_{\text {it }}+\gamma_{9} \text { LDTA }_{\text {it }} * \text { FCDUM }_{\text {it }}+\gamma_{10} \text { DE }_{\text {it }} * \text { FCDUM }_{\text {it }}+ \\
& \gamma_{11} \text { SIZE }_{i t} * \text { FCDUM }_{i t}+\gamma_{12} \text { EFY }_{\text {it }} * \text { FCDUM }_{i t}+\mu_{\text {it }} \\
& +\gamma_{8} \text { SDTA }_{\text {it }} * \text { FCDUM }_{\text {it }}+\gamma_{9} \text { LDTA }_{\text {it }} * \text { FCDUM }_{\text {it }}+\gamma_{10} \text { DE }_{\text {it }} * \text { FCDUM }_{i t}+ \\
& \gamma_{11} \text { SIZE }_{i t} * \text { FCDUM }_{\text {it }}+\gamma_{12} \text { EFY }_{\text {it }} * \text { FCDUM }_{i t}+\mu_{\text {it }}
\end{aligned}
$$

\section{Findings}

Table 2 shows the descriptive statistics of the variables involved in this study. The mean value of Return on Assets (ROA) is $1.65 \%$ whereas its standard deviation is 21.79. This shows that corporate performance of the textile sector of Pakistan has remained volatile over the period of this study, i.e. 1999-2012. Tobin's Q has a mean value of 1.64 times the total asset value of each firm in the sample. Its standard deviation is the third highest which further confirms that corporate performance of the textile sector remained volatile during this period. Short-term debt to total assets (SDTA) has a mean value of 0.623 or $62.3 \%$ with a standard deviation of 1.05. Long-term debt to Total Assets (LDTA) has a mean value of 0.22 (or 22\%) with a standard deviation of 0.207 , and Total Debt to Total Assets (TDTA) has a mean value of 0.84 (or $84 \%$ ) with a standard deviation of 1.04 .

The descriptive analysis also reveals some interesting information regarding the debt financing patterns of firms in textile sector of Pakistan. SDTA has a mean value of $62.3 \%$ which shows that most of the firms are pursuing short term debt financing. Whereas the mean value of LDTA is $22 \%$ which shows that long term debt financing is not very common in Pakistan due to high borrowing cost on long term financing. TDTA has a mean value of $84 \%$ which shows that firms in the textile sector of Pakistan are heavily financed with debt and high percentage of the overall debt financing goes to short term financing as it is quite evident from the mean value of SDTA (i.e., 62.3\%). Similarly, some further insights can be developed regarding capital structure choices of the firms in textile sector of Pakistan. The mean value of Debt to Equity (DE) ratio is 7.02 times equity of each firm included in the sample. It also has the highest variation (as measured by standard deviation) which is 65.8. This implies that the capital structure/financing trends of firms in textile sector have remained highly volatile during the sample period. As the financial leverage did not exhibit high volatility (as shown in table 2), it is quite evident that high volatility in debt to equity ratio is attributable to frequent changes in equity financing. In other words, high volatility in capital structures of textile sector firms in Pakistan during the sample period was not only due to changes in debt financing preferences since the percentage of debt financing did not change much during the sample period as suggested by standard deviation figures, especially that of Total Debt to Total Assets (TDTA). Firm Size (SIZE) has a mean value of 8.91 with a standard deviation of 0.63 . This implies that firms in textile sector of Pakistan are mostly exhibiting uniformity in sizes as measured by total assets of the firm. Firm's efficiency (EFY) has a mean value of 1.18 and a standard deviation of 2.26. This shows that the firms in the sample have performed very well over the sample 
period as the mean value is well over $100 \%$. This shows that most of the firms in the sample are having sales well over their assets and are more efficient.

Table 2: Descriptive statistics

\begin{tabular}{lcccccccc}
\hline & ROA & Tobin Q & SDTA & LDTA & TDTA & DE & SIZE & EFY \\
\hline Mean & 1.65 & 1.64 & 0.623 & 0.22 & 0.84 & 7.02 & 8.91 & 1.18 \\
Median & 1.90 & 0.191 & 0.49 & 0.18 & 0.70 & 2.27 & 8.94 & 1.05 \\
Maximum & 425.04 & 187.42 & 20 & 1.77 & 20 & 2001.38 & 10.66 & 81 \\
Minimum & -301.59 & 0.0006 & 0 & 0 & 0.05 & -178.5 & 4.91 & 0 \\
Std. Dev. & 21.79 & 13.21 & 1.05 & 0.207 & 1.04 & 65.8 & 0.63 & 2.26 \\
\hline
\end{tabular}

Table 3 reports the correlation coefficients for the variables used in this study. As this coefficient shows the degree of linear association between two variables, it can also be used to identify the issue of multicollinearity in a given data set. Multicollinearity is a term which refers to a high correlation between two or more independent variables in a study and thus creates a problem of insignificant coefficients. From the table, it is quite evident that TDTA and SDTA are having a strong positive correlation (i.e. 0.98) with each other. This is due to the fact that firms in the textile sector of Pakistan prefer short term debt in their capital structures. That is why total debt has a high percentage of short term debt and inclusion of this variable along with short term debt creates the issue of multicollinearity in the data. That is why TDTA has been removed for estimation purposes to avoid the issue of multicollinearity. Analysis of other correlation coefficients reveals that there is no incidence of strong correlation (either positive or negative) among the independent variables. Further insights regarding relationships can be developed on further probing into table 3. Return on Assets (ROA) is negatively correlated with financial leverage as measured by SDTA, LDTA, TDTA, and DE. Similarly, when performance is measured using Tobin's, the results are somewhat different. Tobin's Q is positively correlated with TDTA, positively correlated with SDTA, negatively correlated with LDTA, and negatively correlated with DE. Corporate performance when measured by Tobin's Q gives more realistic results keeping in view the debt financing trends in the textile sector of Pakistan.

However, the relationship of SIZE and EFY with corporate performance varies as corporate performance measure changes from ROA to Tobin's Q. When the performance is measured using ROA, both SIZE and EFY are positively correlated with corporate performance. Whereas, when performance is measured using Tobin's Q, both SIZE and EFY become negatively correlated with corporate performance. The negative correlation between firm efficiency (EFY) and Tobin's Q lacks theoretical background and therefore has no theoretical justification. On further analysis during estimation, the relationship between EFY and Tobin's Q was found to be insignificant. This shows that the negative relationship found has no practical meaning in the analysis. The rationale behind negative correlation between Tobin's Q and firm size can be attributed to the difference in the fundamental construction of the measures used for corporate performance. Tobin's Q is a market based measure of corporate performance and the Pakistani market might have considered increasing firm size as a negative sign of firm's financial health as opposed to Return on 
Assets (ROA) which is purely an accounting based measure and thus has a positive correlation with firm size. As ROA does not involve any market sentiment, the nature of relationship with firm size captured by the correlation coefficient is quite predictable and according to traditional theory of finance (as opposed to behavioral finance).

Table 3: Correlation matrix

\begin{tabular}{lcccccccc}
\hline & TQ & ROA & LDTA & TDTA & SDTA & DE & SIZE & EFY \\
\hline TQ & 1 & & & & & & & \\
ROA & $-0.412^{*}$ & 1 & & & & & & \\
LDTA & $-0.109^{* *}$ & -0.058 & 1 & & & & & \\
TDTA & $0.587^{*}$ & $-0.409^{*}$ & 0.055 & 1 & & & & \\
SDTA & $0.603^{*}$ & $-0.394^{*}$ & $-0.141^{* * *}$ & $0.980^{*}$ & 1 & & & \\
DE & -0.009 & -0.021 & 0.070 & 0.010 & -0.003 & 1 & & \\
SIZE & $-0.481^{*}$ & $0.223^{* *}$ & -0.045 & $-0.558^{*}$ & $-0.54512^{*}$ & -0.010 & 1 & \\
EFY & -0.027 & 0.067 & -0.038 & -0.035 & -0.0271 & -0.012 & -0.031 & 1 \\
\hline
\end{tabular}

Note: $* * *$ and $* * *$ indicate significance level at $1 \%, 5 \%$ and $10 \%$, respectively.

Equations 5 and 6 show the estimated coefficients in the overall sample (i.e. 1999-2012) with and without considering the impact of financial crisis on the leverage-performance relationship. The results have been reported in table 4 .

$$
\begin{aligned}
\mathrm{ROA}_{\mathrm{it}}= & 7.39_{\mathrm{it}}-9.63 \mathrm{SDTA}_{\mathrm{it}}-11.82 \mathrm{LDTA}_{\mathrm{it}}-0.003 \mathrm{DE}_{\mathrm{it}}+0.29 \mathrm{SIZE}_{i \mathrm{t}}+0.63 \mathrm{EFY}_{\mathrm{it}} \\
& -2.59 \mathrm{FCDUM}_{\mathrm{it}}+\mu_{\mathrm{it}} \\
\mathrm{ROA}_{\mathrm{it}}= & 14.36_{\mathrm{it}}-10.17 \mathrm{SDTA}_{\mathrm{it}}-12.76 \mathrm{LDTA}_{\mathrm{it}}-0.0039 \mathrm{DE}_{\mathrm{it}}-0.504 \mathrm{SIZE}_{\mathrm{it}} \\
& +0.67 \mathrm{EFY}_{\mathrm{it}}+\mu_{\mathrm{it}}
\end{aligned}
$$

When the financial crisis was not accounted for, the relationship between leverage and financial performance was found to be negative and significant. This shows that debt financing leads to lower financial performance as the borrowing costs are high and the given profitability does not cover all the borrowing costs. Financial leverage as measured by SDTA and LDTA was found to have a negative impact on corporate financial performance. Debt to Equity was also found to have a negative impact but the relationship was insignificant. Firm Size (SIZE) was also found to have a negative impact which suggests that corporate financial performance in the textile sector declines as the firm size increases. This can be due to lack of corporate governance. Firm Efficiency (EFY) was found to have a positive impact on the corporate financial performance.

With the introduction of financial crisis dummy variable in the regression model, it was found that financial crisis negatively affected the corporate financial performance. Since the dummy variable is intercept dummy, it only affected the intercept and the impact became clearly evident. The financial crisis dummy had a significant and negative coefficient. The intercept in this case fell to 7.39 as compared to 14.36 in the equation where financial crisis dummy was not introduced. The intercept shift owing to the financial crisis can be explained using dummy variable technique in a much better way as compared 
to the Chow Test as suggested by Gujarati (2009) in chapter 9, page 303. The coefficients of SDTA and LDTA were again found to be negative and significant which shows that financial leverage had a negative impact on corporate financial performance along with the financial crisis. It also suggests that the financial crisis did not affect the relationship between financial leverage and corporate performance. Debt to Equity (DE) was again found to be negative but insignificant. Firm Size (SIZE) was insignificant in this case whereas firm efficiency (EFY) was found to have a positive and significant impact on corporate financial performance. The issue of heteroscedasticity in the data was resolved using GLS cross-section weights and white cross-section coefficient covariance method which. It applies corrective measures automatically during estimation.

Table 4: Corporate Performance Measured by ROA (1999-2012)

\begin{tabular}{lcccccc}
\hline & & \multicolumn{2}{c}{ Pooled OLS } \\
& With Crisis & $\begin{array}{c}\text { Standard } \\
\text { Error }\end{array}$ & $\begin{array}{c}\mathrm{t}- \\
\text { Statistic }\end{array}$ & Without Crisis & $\begin{array}{c}\text { Standard } \\
\text { Error }\end{array}$ & $\begin{array}{c}\text { t- } \\
\text { Statistic }\end{array}$ \\
\hline Intercept & $7.39 * *$ & 3.012 & 2.453 & $14.36^{*}$ & 2.859 & 5.024 \\
SDTA & $-9.63^{*}$ & 0.811 & -11.86 & $-10.17^{*}$ & 0.810 & -12.55 \\
LDTA & $-11.82^{*}$ & 1.064 & -11.10 & $-12.76^{*}$ & 1.051 & -12.10 \\
DE & -0.003 & 0.0034 & -0.892 & -0.004 & 0.003 & -1.117 \\
SIZE & 0.29 & 0.303 & 0.974 & $-0.504 * * *$ & 0.282 & -1.780 \\
EFY & $0.63^{*}$ & 0.125 & 5.040 & $0.67 *$ & 0.126 & 5.290 \\
FCDUM & $-2.59 *$ & 0.325 & -7.960 & - & - & - \\
R $^{2}$ & 0.200 & - & - & 0.172 & - & - \\
Adj. R & 0.199 & - & - & 0.169 & - & - \\
F-Statistic & $56.92^{*}$ & - & - & $55.97 *$ & - & - \\
\hline
\end{tabular}

Note: $* * * \& * * *$ indicate significance at $1 \%, 5 \%$ and $10 \%$ level, respectively.

Equations 7 and 9 show the estimated coefficients using fixed effects and random effects estimation models in the overall sample (1999-2012) while considering the impact of financial crisis on the leverage-performance relationship. Whereas equations 8 and 10 show the estimated coefficients without considering the impact of financial crisis. The estimation results of FEM and REM are reported in tables 5 and 6, respectively.

$$
\begin{gathered}
\mathrm{ROA}_{\mathrm{it}}=43.14_{\mathrm{i}}-7.72 \mathrm{SDTA}_{\mathrm{it}}-9.41 \mathrm{LDTA}_{\mathrm{it}}-0.000545 \mathrm{DE}_{\mathrm{it}}-3.84 \mathrm{SIZE}_{\mathrm{it}} \\
+0.177 \mathrm{EFY}_{\mathrm{it}} \\
\quad-1.55 \mathrm{FCDUM}_{\mathrm{it}}+\mu_{\mathrm{it}} \\
\mathrm{ROA}_{\mathrm{it}}=56.45_{\mathrm{i}}-8.09 \mathrm{SDTA}_{\mathrm{it}}-9.63 \mathrm{LDTA}_{\mathrm{it}}-0.000184 \mathrm{DE}_{\mathrm{it}}-5.36 \mathrm{SIZE}_{\mathrm{it}} \\
+
\end{gathered}
$$




$$
\begin{aligned}
& \mathrm{ROA}_{\mathrm{it}}=3.45_{\mathrm{i}}-7.7 \mathrm{SDTA}_{\mathrm{it}}-10.27 \mathrm{LDTA}_{\mathrm{it}}-0.0029 \mathrm{DE}_{\mathrm{it}}+0.65 \mathrm{SIZE}_{\mathrm{it}} \\
& +0.42 \mathrm{EFY}_{\text {it }} \\
& -3.07 \text { FCDUM }_{\mathrm{it}}+\mu_{\mathrm{it}} \\
& \mathrm{ROA}_{i t}=10.13_{\mathrm{i}}-8.0 \mathrm{SDTA}_{\mathrm{it}}-11.20 \mathrm{LDTA}_{\mathrm{it}}-0.0033 \mathrm{DE}_{\mathrm{it}}-0.169 \mathrm{SIZE}_{\mathrm{it}} \\
& +0.45 \mathrm{EFY}_{\mathrm{it}}+\mu_{\mathrm{it}}
\end{aligned}
$$

When the fixed effects estimation results were analyzed, one of the major improvements over the OLS estimation was the improvement in $\mathrm{R}^{2}$. The explained variation $\left(\mathrm{R}^{2}\right)$ in the dependent variable increased from 0.2 to 0.439 when the financial crisis was accounted for and from 0.172 to 0.433 when the financial crisis was not considered. The Random Effects (RE) estimation also lacked this feature, i.e. $\mathrm{R}^{2}$ was low though the Hausman test statistic $\left(\chi^{2}=0.00\right)$ led to non-rejection of the null hypothesis. The Fixed Effects (FE) estimation has given far better results as compared to OLS. The Hausman test also allowed considering both fixed effects and random effects models. The results given by REM are similar to those obtained by OLS or Fixed Effects Model (FEM). However, the only improvement FEM brings to the estimation procedure is the improvement in $\mathrm{R}^{2}$ or explained variation. However, there are no econometric limitations in using either of the two techniques since the goodness of fit of the models has been confirmed by the F-test statistic which is significant in both cases. The signs and statistical significance of the estimated coefficients are very similar to those reported in OLS estimation. In the absence of financial crisis, the leverage and financial performance are found to have a negative relationship while being significant at the same time. DE was found to be negative but insignificant. Firm size was found to have a significant negative impact on financial performance of firms in the textile sector for the reason mentioned previously. Firm efficiency was again found to have a positive impact.

When the financial crisis was accounted for, the intercept dummy shifted the intercept downwards which confirms the results of OLS estimation that financial crisis had a negative impact on corporate financial performance. The intercept shifted from 56.45 to 43.14 in the case of fixed effects estimation model and from 10.13 to 3.45 in the case of random effects estimation. The coefficients of SDTA and LDTA were found to be negative and significant which implies that the leverage had a negative impact on financial performance and the financial crisis did not affect the leverage-performance relationship. Firm size had a negative impact on corporate performance whereas firm efficiency had a positive impact.

Table 5: Corporate Performance Measured by ROA (1999-2012)

\begin{tabular}{lcccccc}
\hline & & \multicolumn{2}{c}{ Fixed Effects } \\
& With Crisis & $\begin{array}{c}\text { Standard } \\
\text { Error }\end{array}$ & t-Statistic & Without Crisis & $\begin{array}{c}\text { Standard } \\
\text { Error }\end{array}$ & t-Statistic \\
\hline Intercept & $43.14^{*}$ & 6.432 & 6.707 & $56.45^{*}$ & 4.916 & 11.48 \\
SDTA & $-7.72^{*}$ & 0.976 & -7.908 & $-8.09^{*}$ & 0.961 & -8.417 \\
\hline
\end{tabular}


Financial Leverage and Corporate Performance: Does Financial Crisis Owe an Explanation?

\begin{tabular}{lcccccc}
\hline LDTA & $-9.41^{*}$ & 1.2 & -7.84 & $-9.63^{*}$ & 1.2 & -8.024 \\
DE & -0.000545 & 0.002 & 0.207 & -0.000184 & 0.002 & -0.063 \\
SIZE & $-3.84^{*}$ & 0.712 & -5.39 & $-5.36^{*}$ & 0.537 & -9.975 \\
EFY & $0.177^{* *}$ & 0.077 & 2.28 & $0.181^{* *}$ & 0.07 & 2.37 \\
FCDUM & $-1.55^{*}$ & 0.344 & -4.519 & - & - & - \\
R $^{2}$ & 0.439 & - & - & 0.433 & - & - \\
Adj. R & 0.385 & - & - & 0.38 & - & - \\
F-Statistic & $8.1^{*}$ & - & - & $8.2^{*}$ & - & - \\
\hline
\end{tabular}

Note: $* * * \& * * *$ indicate significance at $1 \%, 5 \%$ and $10 \%$ level, respectively.

Table 6: Corporate Performance Measured by ROA (1999-2012)

\begin{tabular}{lcccccc}
\hline & & \multicolumn{5}{c}{ Random Effects } \\
& With Crisis & $\begin{array}{c}\text { Standard } \\
\text { Error }\end{array}$ & t-Statistic & Without Crisis & $\begin{array}{c}\text { Standard } \\
\text { Error }\end{array}$ & t-Statistic \\
\hline Intercept & $3.45^{*}$ & 10.68 & 0.323 & $10.13^{*}$ & 10.383 & 0.976 \\
SDTA & $-7.7^{*}$ & 0.673 & -11.43 & $-8.0^{*}$ & 0.665 & -12.03 \\
LDTA & $-10.27^{*}$ & 2.77 & -3.698 & $-11.20^{*}$ & 2.756 & -4.09 \\
DE & -0.0029 & 0.008 & -0.357 & -0.0033 & 0.008 & -0.41 \\
SIZE & 0.65 & 1.165 & 0.559 & -0.169 & 1.124 & -0.15 \\
EFY & $0.42^{* * *}$ & 0.236 & 1.816 & $0.45^{* * *}$ & 0.236 & 1.912 \\
FCDUM & $-3.07^{*}$ & 1.162 & -2.646 & - & - & - \\
$\mathrm{R}^{2}$ & 0.135 & - & - & 0.131 & - & - \\
Adj. $\mathrm{R}^{2}$ & 0.131 & - & - & 0.128 & - & - \\
F-Statistic & $35.01^{*}$ & - & - & $40.55^{*}$ & - & - \\
\hline
\end{tabular}

Note: $* * * \& * * *$ indicate significance at $1 \%, 5 \%$ and $10 \%$ level, respectively.

Equations 11 and 12 show the estimated coefficients with and without considering the impact of financial crisis on corporate performance (Tobin's Q), respectively. Estimation results have been reported in table 7 .

$$
\begin{gathered}
\text { TobinQ }_{\text {it }}=41.08_{\text {it }}+5.807 \text { SDTA }_{\text {it }}-3.74 \mathrm{LDTA}_{\mathrm{it}}-0.001 \mathrm{DE}_{\mathrm{it}}-4.97 \mathrm{SIZE}_{\mathrm{it}} \\
-0.13 \mathrm{EFY}_{\mathrm{it}} \\
-1.119 \mathrm{FCDUM}_{\mathrm{it}}+\mu_{\mathrm{it}} \\
\text { TobinQ }_{\mathrm{it}}=42.96_{\mathrm{it}}+5.9 \mathrm{SDTA}_{\mathrm{it}}-3.4 \mathrm{LDTA}_{\mathrm{it}}-0.001 \mathrm{DE}_{\mathrm{it}}-4.73 \mathrm{SIZE}_{\mathrm{it}} \\
-0.14 \mathrm{EFY}_{\mathrm{it}}+\mu_{\mathrm{it}}
\end{gathered}
$$

When financial crisis was not considered and corporate performance was measured by Tobin's Q. The leverage-performance relationship changed as compared to that obtained by using ROA as the corporate performance measure. But this is not against the findings of previous studies. The leverage-performance relationship has remained controversial ever since research started in this strand of literature (e.g. Modigliani \& Miller, 1958). The 
short-term debt was found to have a positive impact on corporate financial performance whereas the long term debt was found to have a negative impact on firm performance. Since Tobin's Q ratio is a market based measure with market value being the numerator in its calculation, it is quite evident that this ratio represents the entire market's view on a firm's financial performance and this should not come as a surprise when short term debt is found to have a positive impact on firm performance as the market participants in Pakistan might have considered increasing short term debt in capital structure as a positive sign for firm's financial health. The negative sign of LDTA shows that market participants did not consider long term debt to be favorable for a firm's financial health. The results are however significant and according to theory. There is a reasonable amount of debate on the true nature of leverage-performance relationship as discussed in literature review section. The relationship changes as the corporate performance measure changes from ROA to Tobin's Q and the reason is quite logical and justifiable, i.e. ROA is a book based measure which considers debt to have a negative impact no matter if its long term or short term in nature whereas Tobin's Q is a market based measure and whatever the market participants opine about debt financing, that becomes evident when we regress leverage variables with Tobin's Q ratio. These results are in line with the findings of previous studies (Salim \& Yadav, 2012; San \& Heng, 2011). Debt to Equity (DE) also had a negative but insignificant impact on corporate financial performance.

When the financial crisis was considered, the results were similar to those obtained by using ROA as the corporate performance measure. Financial crisis again had a negative impact on corporate performance as indicated by the downward intercept shift (i.e. from 42.96 to 41.08). SDTA had a positive and significant impact on corporate performance whereas LDTA had a negative impact on corporate performance. Further probing into this relationship reveals that financial crisis did not affect the leverage-performance relationship when financial crisis dummy was introduced in the analysis. This can be confirmed by comparing the signs of coefficients of SDTA and LDTA in both cases in table 7. DE had a negative but insignificant impact on corporate performance. Firm size was again found to have a negative and significant impact on corporate performance whereas firm efficiency remained insignificant. 
Table 7: Corporate Performance Measured by Tobin's Q (1999-2012)

\begin{tabular}{lllllll}
\hline & & \multicolumn{9}{c}{ Pooled OLS } & Standard & t- \\
& With Crisis & $\begin{array}{l}\text { Standard } \\
\text { Error }\end{array}$ & $\begin{array}{l}\mathrm{t} \text { - } \\
\text { Statistic }\end{array}$ & Without Crisis & $\begin{array}{l}\text { Stan } \\
\text { Error }\end{array}$ & Statistic \\
\hline Intercept & $41.08^{*}$ & 5.036 & 8.53 & $42.96^{*}$ & 4.933 & 8.326 \\
SDTA & $5.807^{*}$ & 0.326 & 17.76 & $5.9^{*}$ & 0.323 & 18.25 \\
LDTA & $-3.74^{*}$ & 1.395 & -2.68 & $-3.4^{*}$ & 1.384 & -2.46 \\
DE & -0.001 & 0.004 & -0.368 & -0.001 & 0.004 & -0.329 \\
SIZE & $-4.97^{*}$ & 0.547 & -9.08 & $-4.73^{*}$ & 0.531 & -8.89 \\
EFY & -0.13 & 0.123 & -1.068 & -0.14 & 0.123 & -1.133 \\
DUM & $-1.119 *$ & 0.614 & 1.82 & - & - & - \\
R & 0.401 & - & - & 0.4 & - & - \\
Adj. R ${ }^{2}$ & 0.399 & - & - & 0.398 & - & - \\
F-Statistic & $149.79 *$ & - & - & 178.77 & - & - \\
\hline
\end{tabular}

Note: $* * * \& * * *$ indicate significance at $1 \%, 5 \%$ and $10 \%$ level, respectively.

Equations 13 and 15 show the estimated coefficients in the overall sample (i.e. 1999-2012) using fixed and random effects estimation models respectively while considering the impact of financial crisis on corporate performance. Equations 14 and 16 show the estimated coefficients in the overall sample using fixed and random effects estimation models respectively without considering the impact of financial crisis on corporate financial performance. Estimation results of FEM and REM are reported in tables 8 and 9, respectively.

$$
\begin{aligned}
& \text { Tobin }_{\text {it }}=5.89_{\mathrm{i}}+0.31 \mathrm{SDTA}_{\mathrm{it}}-0.05 \mathrm{LDTA}_{\mathrm{it}}-0.000141 \mathrm{DE}_{\mathrm{it}}-0.49 \mathrm{SIZE}_{\mathrm{it}} \\
& -0.0014 \mathrm{EFY}_{\mathrm{it}} \\
& -0.097 \text { FCDUM }_{\mathrm{it}}+\mu_{\mathrm{it}} \\
& \text { TobinQ } \mathrm{it}_{\mathrm{it}}=9.89_{\mathrm{i}}+0.005 \mathrm{SDTA}_{\mathrm{it}}-0.284 \mathrm{LDTA}_{\mathrm{it}}-0.000449 \mathrm{DE}_{\mathrm{it}}-0.91 \mathrm{SIZE}_{\mathrm{it}} \\
& -0.0032 \mathrm{EFY}_{\mathrm{it}}+\mu_{\mathrm{it}} \\
& \text { TobinQ }_{\text {it }}=76.55_{\mathrm{i}}+2.37 \mathrm{SDTA}_{\mathrm{it}}-2.29 \mathrm{LDTA}_{\mathrm{it}}-0.000893 \mathrm{DE}_{\mathrm{it}}-9.58 \mathrm{SIZE}_{\mathrm{it}} \\
& -0.09 \mathrm{EFY}_{\text {it }} \\
& -2.27 \text { FCDUM }_{\text {it }}+\mu_{\text {it }} \\
& \text { TobinQ }_{i t}=85.45_{\mathrm{i}}+2.706 \mathrm{SDTA}_{\mathrm{it}}-1.54 \mathrm{LDTA}_{\mathrm{it}}-0.000564 \mathrm{DE}_{\mathrm{it}}-8.53 \mathrm{SIZE}_{\mathrm{it}} \\
& -0.11 \mathrm{EFY}_{\mathrm{it}}+\mu_{\mathrm{it}}
\end{aligned}
$$

On using Fixed Effects model, one of the major improvements over OLS estimation was increase in $\mathrm{R}^{2}$ (or explained variation in the dependent variable) as was the case when ROA equation was estimated using Fixed Effects technique and increase in the goodness of fit of the model. The $\mathrm{R}^{2}$ increased from 0.399 to 0.55 when financial crisis was considered and from 0.4 to 0.57 when financial crisis was not considered. The estimated coefficients of SDTA and LDTA remained the same across the two estimations, i.e. SDTA was found to have a positive impact whereas LDTA was found to have a negative impact on firm 
performance. All these coefficients were significant. Debt to Equity was found to have a negative and significant impact in fixed effects estimation. Firm size was found to have a negative impact on firm performance whereas firm efficiency remained insignificant as was found when the equation was estimated using OLS technique. Estimation results were the same in this case as indicated by Hausman test $\left(\chi^{2}=0.00\right)$ which leads to the nonrejection of null hypothesis. This means that either of the estimation techniques can be used to estimate the equations. But fixed effects model gave significant results.

When financial crisis was considered, the intercept dummy shifted the intercept downward (i.e. from 9.89 to 5.89) which implies that financial crisis had a negative impact on firm performance. However, the leverage-performance relationship was not affected by the financial crisis. The only difference observed across estimations using ROA and Tobin's $\mathrm{Q}$ as the corporate performance measure was in the nature of leverage-performance relationship. When the performance was measured using ROA, all leverage variables indicated a negative impact on firm's financial performance whereas in the case of Tobin's Q, only SDTA changed its sign from negative to positive due to the reasons mentioned previously. When the Tobin's Q equation was estimated using Random Effects technique, the results were similar to those obtained by either OLS or Fixed Effects in terms of signs of the coefficients and the impact of financial crisis on performance. The only difference lies in the explanatory power of the model and significance of the estimated coefficients which have been increased in the case of Fixed Effects Model (FEM).

Table 8: Corporate Performance Measured by Tobin's Q (1999-2012)

\begin{tabular}{lcccccc}
\hline & & \multicolumn{5}{c}{ Random Effects } \\
& With Crisis & $\begin{array}{c}\text { Standard } \\
\text { Error }\end{array}$ & $\begin{array}{c}\mathrm{t} \text { - } \\
\text { Statistic }\end{array}$ & Without Crisis & $\begin{array}{c}\text { Standard } \\
\text { Error }\end{array}$ & $\begin{array}{c}\text { t- } \\
\text { Statistic }\end{array}$ \\
\hline Intercept & $76.55^{*}$ & 5.734 & 14.9 & $85.45^{*}$ & 5.514 & 13.88 \\
SDTA & $2.37^{*}$ & 0.33 & 7.184 & $2.706^{*}$ & 0.329 & 8.204 \\
LDTA & $-2.29 * * *$ & 1.269 & -1.808 & -1.54 & 1.276 & -1.213 \\
DE & -0.000893 & 0.0034 & -0.259 & -0.000564 & 0.0034 & -0.16 \\
SIZE & $-9.58^{*}$ & 0.631 & -15.16 & $-8.53 *$ & 0.60 & -14.16 \\
EFY & -0.09 & 0.1 & -0.95 & -0.11 & 0.102 & -1.09 \\
FCDUM & $-2.27 *$ & 0.494 & 4.608 & - & - & - \\
R $^{2}$ & 0.232 & - & - & 0.224 & - & - \\
Adj. R & 0.228 & - & - & 0.221 & - & - \\
F-Statistic & $67.39 *$ & - & - & $77.62 *$ & - & - \\
\hline
\end{tabular}

Note: ${ }^{*}{ }^{* *} \& * * *$ indicate significance at $1 \%, 5 \%$ and $10 \%$ level, respectively.

Table 9: Corporate Performance Measured by Tobin's Q (1999-2012) 
Fixed Effects

\begin{tabular}{lcccccc} 
& With Crisis & $\begin{array}{c}\text { Standard } \\
\text { Error }\end{array}$ & $\begin{array}{c}\mathrm{t} \text { - } \\
\text { Statistic }\end{array}$ & Without Crisis & $\begin{array}{c}\text { Standard } \\
\text { Error }\end{array}$ & $\begin{array}{c}\mathrm{t} \text { - } \\
\text { Statistic }\end{array}$ \\
\hline Intercept & $5.89 *$ & 0.678 & 8.688 & $9.89 *$ & 1.388 & 7.12 \\
SDTA & $0.31^{*}$ & 0.098 & 3.15 & $0.005^{*}$ & 0.117 & 0.048 \\
LDTA & $-0.05^{*}$ & 0.095 & -0.569 & $-0.284^{*}$ & 0.065 & -4.32 \\
DE & $-0.000141^{* *}$ & 0.0696 & -2.02 & $-0.000449 *$ & 0.0173 & -2.59 \\
SIZE & $-0.49 *$ & 0.075 & -6.54 & $-0.91 *$ & 0.158 & -5.8 \\
EFY & -0.0014 & 0.001 & 0.926 & -0.0032 & 0.004 & 0.759 \\
FCDUM & $-0.097 *$ & 0.027 & -3.52 & - & - & - \\
$\mathrm{R}^{2}$ & 0.55 & - & - & 0.57 & - & - \\
Adj. R & 0.50 & - & - & 0.53 & - & - \\
F-Statistic & $12.85^{2}$ & - & - & $14.23 *$ & - & - \\
\hline
\end{tabular}

Note: ${ }^{*} * * \& * * *$ indicate significance at $1 \%, 5 \%$ and $10 \%$ level, respectively.

Of all the models that have been estimated, Fixed Effects Model (FEM) gave the most reliable results in terms of explanatory power of the model $\left(\mathrm{R}^{2}\right)$ and significance of results although Hausman test failed to reject the null hypothesis, i.e. either of the two estimation techniques could be used. Long-term and short-term debt ratios were found to have a negative impact on corporate performance. These results are in line with those of Salim and Yadav (2012), San and Heng (2011), and Ebaid (2009). The negative relationship of financial leverage with corporate performance is quite evident from the fact that cost of borrowing is very high in Pakistan, not only in the long term but also in the short term. In addition to this, there are no developed debt capital markets for issuing long term debt instruments. So, firms are forced to borrow from banks at both short- and long-terms. Since the cost of borrowing in long term is high, firms face difficulties in making principal and interest payments to banks (being the only source of debt financing for many firms). Corporate profitability greatly suffers due to excessive use of long term debt as interest payments are usually very high. This is the reason why firms mostly go for short term financing. But short term financing has its own drawbacks. Some firms cannot afford to borrow even on a short terms as their liquidity position does not allow it. So, when they do, their performance declines as a result as they have to pay back their loans on a short term basis.

Finally, the interaction term(s) (see eq. $3 \& 4$ ) was used to access the change in leverageperformance relation under financial crises. When performance was measured by ROA, long term debt to total assets was found to have a negative and significant impact on 
corporate performance (see table 10). Short term debt to total assets coefficient which is negative in case of ROA became positive and significant for Tobin's Q (except with FEM estimation) which implies that firms with short term financing were able to manage superior performance. This change in the nature of relationship is also attributable to the fact that market based measure was now used to estimate the equation. Since Tobin's Q ratio is a market based measure with market value being the numerator in its calculation, it is quite evident that this ratio represents the entire market's view on a firm's financial performance and this should not come as a surprise when short term debt is found to have a positive impact on firm performance as the market participants in Pakistan might have considered increasing short term debt in capital structure as a positive sign for firm's financial health. The negative sign of LDTA shows that market participants did not consider long term debt to be favorable for a firm's financial health. The results are however significant and according to theory. There is a reasonable amount of debate on the true nature of leverage-performance relationship as discussed in literature review. The relationship changes as the corporate performance measure changes from ROA to Tobin's $\mathrm{Q}$ and the reason is quite logical and justifiable, i.e. ROA is a book based measure which considers debt to have a negative impact no matter if its long term or short term in nature whereas Tobin's Q is a market based measure and whatever the market participants opine about debt financing, that becomes evident when we regress leverage variables with Tobin's Q ratio. These results are again similar to those of Ebaid (2009), San and Heng (2011), and Salim and Yadav (2012).

The inclusion of financial crisis dummy variable as an interaction term in the analysis helped in investigating whether financial crisis owes any explanation in affecting corporate financial performance or not. Since the inquiry into the nature of impact of financial crisis was required, both regression equations (ROA \& Tobin's Q as dependent variable) were estimated under different model specification. The magnitude of impact of short term debt on firms' performance increases during crises although the nature (with ROA \& Tobin's Q) is different as justified in previous paragraph. Crises can hit a yield curve in an unanticipated way. An upward or flat yield curve may have an abrupt increase in short term rates without effecting the longer term expectations of the market participants and may increase the leverage-performance relation in magnitude. The impact of long term debt on the performance is negative under normal financial market conditions but becomes positive (when performance is measured through Tobin's Q) during the crises. During crises, financial markets generally lack liquidity and hence the cost of borrowing increases due to uncertainty of interests rates. Firms financed with long term debt and with lower short term financial needs, may not have to borrow at higher costs and this phenomenon logically supports the positive impact of long term debt during crises. 
Table 10: Estimation results with financial crises dummy introduced as interactive term (1999 - 2012)

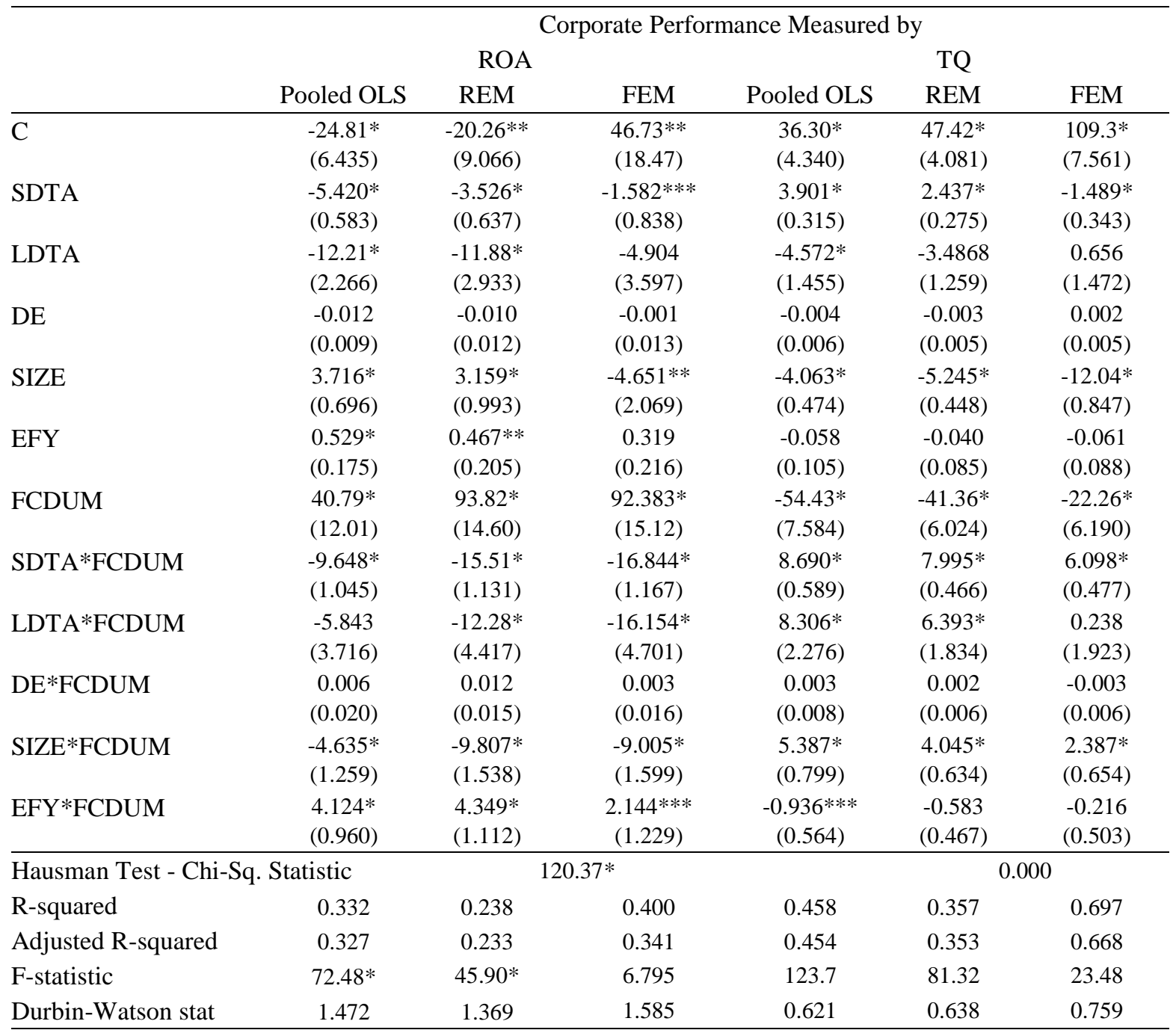

Note: $* * * \& * * *$ indicate significance at $1 \%, 5 \%$ and $10 \%$ level, respectively. Numbers(s) in the parentheses present the standard errors.

\section{Conclusion}

This study investigated the relationship between financial leverage and corporate performance and analyzed annual data of 112 companies from the textile sector of Pakistan over a period of fourteen years (1999-2012). A dummy variable was used to capture the impact of financial crisis on corporate performance. Long term debt to total assets, short term debt to total assets, total debt to total assets, and debt to equity ratios were used as proxies for financial leverage out of which total debt to total assets was excluded from the analysis based on a preliminary diagnostic test of the presence of multicollinearity in the data. Regression equations were estimated for both measures of corporate financial performance, i.e., ROA and Tobin's Q. For each performance measure, three estimation techniques namely Fixed Effects, Random Effects, and Pooled OLS, were used to estimate the regression equations in two situations. First, the regression equations were estimated 
without the inclusion of financial crisis dummy and then after the inclusion of financial crisis dummy variable. Out of these estimation techniques, FEM produced better results in terms of $\mathrm{R}^{2}$ which have been reported in previous sections and have been commented on in great depth. It can be stated that long term debt was found to have a negative impact on corporate performance except during crises and when performance was measured by Tobin's Q. Short term debt was also found to have a negative impact on corporate performance when performance was measured by ROA. It changed the sign(s) as soon as performance measure changed from ROA to Tobin's Q. The results of this study suggest that there is no definite answer to the question whether financial leverage and corporate performance are positively or negatively related. Many theories exist and each theory has its own academic stance. But the findings of this study further confirm that the above said relationship depends on so many factors which cannot be incorporated in one research model to ascertain the truth of this relationship.

As far as the financial crisis is concerned, it had a negative impact on firm performance. This finding remained consistent across both performance measures, i.e. ROA and Tobin's Q. The impact of financial crisis on firm performance was investigated using dummy variable technique and intercept dummy was used to identify its impact. For this reason, two regression equations were estimated for each performance measure, i.e. before inclusion of financial crisis dummy in the equation and after the inclusion of financial crisis dummy variable. In this way, the intercept shift became clearly visible. The intercept was observed before the inclusion of financial crisis dummy and it was compared with that estimate after inclusion of the financial crisis dummy. In all estimations, a downward intercept shift was observed along with a negative slope coefficient for the financial crisis dummy variable. This implies that financial crisis had a negative impact on corporate financial performance. Finally, financial crises dummy as interaction term is used to gauge the magnitude of relation which increases during crises and even changed the sign for long term debt and performance relation. The question 'Did Financial Crisis Own an Explanation' asked in the title has been answered in a very comprehensive manner which has not been done by previous studies. And the answer to that question is 'yes'.

\section{Policy Implications}

The results of this study can help today's managers to assess the optimal level of debt financing that they may afford at any one time without high cost to the firm. There has to be a balance between debt and equity financing and this balance can only be obtained by a shrewd manager who can keep all the factors (both internal and external to the firm) in view while deciding about the capital structure of a firm. As this study has so far talked about debt financing, managers should focus on the factors which might increase the cost of debt for a firm. In cases where potential costs of debt financing are greater and equity financing is also expensive, a firm's management should try to obtain funds from internal financing sources.

\section{References}

1. Abor, J. (2005). The Effect of Capital Structure on Profitability: An Empirical Analysis of Listed Firms in Ghana. Journal of Risk Finance, 6(5), 438-445. 
2. Akhtar, S., Javed, B., Maryam, A., \& Sadia, H. (2012). Relationship between Financial Leverage and Financial Performance: Evidence from Fuel \& Energy Sector of Pakistan. European Journal of Business and Management, 4(11), 7-17.

3. Amjad, R., \& Din, M. U., (2010). Economic and Social Impact of Global Financial Crisis: Implications for Macroeconomic and Development Policies in South Asia. http://mpra.ub.uni-muenchen.de/38150/1/MPRA_paper_38150.pdf.

4. Bhabra, H. S., Liu, T., \& Tirtiroglu, D. (2008). Capital Structure Choice in a Nascent Market: Evidence from Listed Firms in China. Financial Management, 37(2), 341-364.

5. Baker, S. H. (1973). Risk, Leverage and Profitability: An Industry Analysis. The Review of Economics and Statistics, 55(4), 503-507.

6. Ebaid, I. E. S. (2009). The Impact of Capital-structure Choice on Firm Performance: Empirical Evidence from Egypt. Journal of Risk Finance, 10(5), 477487.

7. Gujarati, D. (2009). Basic Econometrics. The McGraw-Hill, New York, USA.

8. Hurdle, G. J. (1974). Leverage, Risk, Market Structure and Profitability. The Review of Economics and Statistics, 478-485.

9. Khan, A. G. (2012). The Relationship of Capital Structure Decisions with Firm Performance: A Study of the Engineering Sector of Pakistan. International Journal of Accounting and Financial Reporting, 2(1), Pages 245-262.

10. Jensen, M. C., \& Meckling, W. H. (1976). Agency Costs and the Theory of the Firm. Journal of Financial Economics, 3(4), 305-360.

11. Modigliani, F., \& Miller, M. H. (1958). The Cost of Capital, Corporation Finance and the Theory of Investment. The American Economic Review, 48(3), 261-297.

12. MacKay, P., \& Phillips, G. M. (2005). How Does Industry Affect Firm Financial Structure?. Review of Financial Studies, 18(4), 1433-1466.

13. Murphy Jr, J. E. (1968). Effect of Leverage on Profitability, Growth and Market Valuation of Common Stock. Financial Analysts Journal, 121-123.

14. Opler, T. C., \& Titman, S. (1994). Financial Distress and Corporate Performance. The Journal of Finance, 49(3), 1015-1040.

15. Qureshi, M. A., \& Azid, T. (2006). Did They Do It Differently? Capital Structure Choices of Public and Private Sectors in Pakistan. The Pakistan Development Review, 701-709.

16. Salim, M., \& Yadav, R. (2012). Capital Structure and Firm Performance: Evidence from Malaysian Listed Companies. Procedia-Social and Behavioral Sciences, 65, 156-166.

17. San, O. T., \& Heng, T. B. (2011). Capital Structure and Corporate Performance of Malaysian Construction Sector. International Journal of Humanities and Social Science, 1(2), 28-36.

18. Shah, A., Hijazi, T., \& Javed, A. Y. (2004). The Determinants of Capital Structure of Stock Exchange-listed Non-financial Firms in Pakistan. The Pakistan Development Review, 605-618. 
19. Shah, S. A. (2007). Corporate Debt Policy - Pre-and Post-financial Market Reforms: The Case of the Textile Industry of Pakistan. The Pakistan Development Review, 465-478.

20. Tobin, J. (1957). Consumer Debt and Spending: Some Evidence from Analysis of a Survey. Consumer Installment Credit. NBER. Washington, US Government Printing Office, (Part II), 217-245.

\section{Appendix 1: Proxies and Formulae}

Dependent Variable: Corporate Performance

Accounting Based Measure

\begin{tabular}{|c|c|}
\hline Proxy & Formula \\
\hline Return on Assets (ROA) & Net Profit before Tax \\
\cline { 2 - 2 } & Average (Non Current Assets + Current Assets) \\
\hline
\end{tabular}

Market Based Measure

\begin{tabular}{|c|c|}
\hline Tobin's Q ratio (TQ) & $\frac{\text { Total Market Value of Firm }}{\text { Total Asset Value }}$ \\
\hline Independent Variable: Financial Leverage & $\frac{\text { Total Debt }}{\text { Total Assets }}$ \\
\hline Total Debt to Total Assets (TD) & $\frac{\text { Short Term Debt }}{\text { Total Assets }}$ \\
\hline Short-Term Debt to Total Assets (STD) & $\frac{\text { Long Term Debt }}{\text { Total Assets }}$ \\
\hline Long-Term Debt to Total Assets (LTD) & $\frac{\text { Total Debt }}{\text { Total Equity }}$ \\
\hline Total Debt to Total Equity (DE) & Log (Total Assets of Firm) \\
\hline Control Variables & $\frac{\text { Sales }}{2}$ \\
\hline Firm Size (FS) & Current + NonCurrent Assets \\
\hline
\end{tabular}

